\title{
Rainer Maria Rilke e Paula Modersohn-Becker Um diálogo inspirador no Réquiem a uma
}

\author{
Amiga
}

\author{
[Rainer Maria Rilke and Paula Modersohn-Becker \\ An inspiring dialogue in the Requiem for a Friend] \\ http://dx.doi.org/10.11606/1982-88372444271
}

\author{
Kathrin Rosenfield ${ }^{1}$ \\ Lawrence Flores Pereira ${ }^{2}$
}

\begin{abstract}
This paper presents Rilke's Requiem to a Friend (with a translation at the end of the article) with some essayistic reflections on the place of this poem about Paula ModersohnBecker's death in the life and the work of the poet. We will begin with biographical observations about Clara Westhoff and her friend Paula meeting Rilke in Paris in 1900 - an encounter that occasioned the study of landscape painting and a small book by Rilke about the artist colony of Worpswede in northern Germany. The strong impact that these encounters - and in particular the analysis of Paula Modersohn-Becker's canvases in 1905 - had on Rilke's poetic sensibility contributed to the new stylistic form (Dingwendung) that manifests itself in Rilke's mature work. We thus present a moment in life and a specific aspect of the development of the relationship of the poet and his work to the fine arts, and of poetry as an artistic process of mourning which announces the mature phase of the Sonnets and the Elegies.
\end{abstract}

Keywords: Rilke; Paula Modersohn-Becker; Painting; Mourning; Poetry.

Resumo: Este artigo apresenta o Réquiem a uma Amiga (tradução no final do artigo) com algumas reflexões ensaísticas sobre o lugar desse poema na obra do poeta R. M. Rilke. Iniciaremos com observações biográficas (os encontros do poeta com a escultora Clara Westhoff e sua amiga Paula em Paris em 1900) que ocasionaram o estudo da pintura de paisagem e um pequeno livro de ocasião de Rilke sobre a colônia de artistas de Worpswede, no norte da Alemanha. O forte impacto que esses encontros - e em particular a análise das telas de Paula Modersohn-Becker em 1905 - tiveram sobre a sensibilidade poética de Rilke contribuíram para a nova forma estilística (Dingwendung) que se manifesta na obra madura de Rilke. Apresentamos assim um momento de vida e um aspecto específico do desenvolvimento da relação do poeta e de sua obra com as artes plásticas, que ilumina o papel da poesia como trabalho de luto do poeta e como prefiguração das obras da fase madura dos Sonetos e das Elegias.

Palavras-chave: Rilke; Paula Modersohn-Becker; Pintura; Luto; Poesia.

\footnotetext{
${ }^{1}$ Universidade Federal do Rio Grande do Sul, Instituto de Filosofia e Ciências Humanas, Av. Bento Gonçalves, 9500, Porto Alegre, RS, 91509-900, Brasil. E-mail: kathrinrosen@gmail.com. ORCID: 00000002-0061-3208

${ }^{2}$ Universidade Federal de Santa Maria, Av. Roraima, 1000, Santa Maria, RS, 97105-900, Brasil. E-mail: lawflores3@gmail.com. ORCID: 0000-0002-4951-3849
}

\section{(cc) BY-NC}

Pandaemonium, São Paulo, v. 24, n. 44, set.-dez. 2021, p. 271-295 
ROSENFIELD, K.; PEREIRA, L. - Um diálogo inspirador no Réquiem a uma Amiga

Não é a uma amiga qualquer que Rilke se dirige no Réquiem que escreveu para Paula Modersohn-Becker. Ele lamenta a morte de uma amiga-artista, ou talvez mais: de uma alma-gêmea. Paula Modersohn-Becker (1876-1907), a pintora que hoje é um dos nomes mais representativos do primeiro expressionismo alemão, faleceu aos trinta anos, depois do parto da única filha, Mathilde. Rainer Maria Rilke (1875-1926) descobrira seu talento apenas dois anos antes, embora tenha conhecido Paula já em 1900, em Paris, onde ela passou alguns meses com a escultora Clara Westhoff (1878-1954), sua mais próxima amiga e futura esposa de Rilke. Mas, em 1905, quando Rilke, já separado, passou o Natal com Clara e a filha na colônia de artistas de Worpswede ${ }^{3}$, ele descobriu não só o talento, mas a artesania, a intensidade e a ousadia inovadora de suas telas, que o impressionaram pelo potencial de abrir novos caminhos para a arte. Rilke então a encorajou a não apenas deixar Worpswede como a se dedicar por inteiro à sua obra.

É essa afinidade que emerge em cada linha desse diálogo do poeta com a artista que morreu jovem demais, sem ter tempo de firmar sua promissora obra ou de mostrar, numa primeira grande exposição, o impressionante caminho que percorreu com suas quase duzentas telas pintadas nos poucos anos entre o início da carreira, em torno de 1900, e sua morte, em 1907. Rilke presta homenagem a essa grandeza, o que dá ao Réquiem o tom peculiar de um encontro entre iguais: o que os une é o modo novo e peculiar de extrair a transcendência da arte da concretude das próprias coisas e criaturas - humanas, animais, vegetais ou minerais. Rilke parece conjurar a artista - ou melhor: a morta parece transfixar Rilke - nessa dimensão de sua arte que se torna o foco do diálogo. No espelho da amiga, ele vê a dificuldade dele de deixar essa arte/artista desaparecer no mundo dos mortos. Por mais que o poeta atribua a ela, à morta, algum desejo de permanecer e de encontrar os vivos naquele limiar entre aquém e além, seus versos desvelam que ela já tem sua própria sobrevida na eternidade, pois teve a coragem de acolher as coisas deixando-as ser como

\footnotetext{
${ }^{3}$ A exemplo do grupo de artistas franceses reunidos desde o final da década de 1880 em Pont Aven, na Bretanha - tendo Paul Gauguin (1848-1903) como vórtice -, o grupo de Worpswede igualmente buscava, em sua gênese, uma outra experiência de modernidade; longe da cidade, esses artistas se voltavam para os ritmos próxima à terra. Instaurada em 1889, a "colônia de artistas" foi em parte influenciada pela crítica cultural de Julius Langbehn (1851-1907), e contava com artistas famosos pela prática da pintura de paisagens - entre eles Willelm Leibl (1844-1900), Otto Modersohn (1865-1943), Heinrich Vogeler (18721942), Fritz Mackensen (1866-1953). Eles buscavam, na vivência em um ambiente rural, recuperar e representar a natureza e a paisagem e as coisas não tocadas pelo turbilhão dos interesses da civilização uma busca típica da época que não deve ser imediatamente associado com o conservadorismo que mais tarde produziria afinidades perigosas com movimentos ideológicos nacionalistas e "völkisch". Os conceitos de Volk, Kultur e Natur certamente não estavam estranhos ao movimento de Worpswede, embora não convêm associá-lo à política cultural nacionalista e fascista mais tardia. Paula Modersohn-Becker estava ainda no início de sua formação quando visitou pela primeira vez essa Künstlerkolonie Worpswede, que continuou atraindo artistas por décadas.
}

Pandaemonium, São Paulo, v. 24, n. 44, set.-dez. 2021, p. 271-295 
ROSENFIELD, K.; PEREIRA, L. - Um diálogo inspirador no Réquiem a uma Amiga

são, soltando-as e soltando-se num outro espaço inconcebível. É essa ousadia de artista que convoca Rilke agora. Sem qualquer recurso a entidades míticas ou sobre-humanas (anjos, Orfeu), o poeta cumpre seu trabalho de luto, dando conta da grandeza e do valor de uma vida que se (des)materializou nas telas. O lugar espectral entre vida e morte no qual se cumpre esse rito de transição parece nascer naturalmente dos respectivos poderes de "transfigurar" que o poeta e a pintora compartilham - aquela liberdade de aceitar a morte simbólica e a perda que o manejo artístico da linguagem exige para tornar o gesto de pintar o escrever criativo.

Pois isto é culpa, se é que alguma culpa exista:

Não aumentar a liberdade do ente amado

Com toda a liberdade que se traz em si.

$[\ldots]$

E o artista em seu ofício às vezes intui

Que ele deve transmutar, sempre que ele ama.

São estas duas coisas que tu começaste...

[...]

E nada quiseste salvo uma vasta obra, [...] (RILKE 1996 II: 420s. vv. 230-249)

O estilo e o tom do Réquiem parecem emular a simplicidade grandiosa da modernidade de Paula. Tematicamente marcado pelas naturezas-mortas, pela presença do feminino e, em grande medida, dela mesma, seu trabalho foi pioneiro na subtração do tratamento e dos símbolos convencionais. Com esse "menos", ela dissolve a representação convencional em brutos planos coloridos, dos quais emergem com tanto mais força olhares penetrantes e expressões emocionais que atravessam o espectador, ao mesmo tempo em que amalgama rostos e figuras com o plano de fundo, com a paisagem, igualando e reconciliando o humano com o todo das coisas. Nesse poema, Rilke se expõe, se deixa penetrar pelo espírito de Paula e transforma num derradeiro canto a arte da amiga que mostrou o caminho mais curto e simples para o âmago da emoção, da dor, da alegria e da elevação espiritual e reflexiva. Ele se inspira na técnica dessa pioneira, cuja linguagem já trilhara os caminhos festejados na obra de Cézanne (1839-1906), e isso antes de descobrir o então 'desconhecido', numa galeria parisiense, em 1900.

Nas telas de Paula, a transcendência não precisa mais de símbolos de elevação; ela cria elos novos com o estado elusivo da morte e contempla o além na miudeza das coisas deste mundo. Nessa dimensão difícil de nomear, os versos de Rilke procuram captar a pintora, e ela aparece ora como um espírito irrequieto que busca voltar do além (RILKE 1996 I: 415 vv. 29-32), ora ela têm a aura segura e serena, como a presença cândida e plena da ingenuidade infantil (RILKE 1996 I: 415 vv. 33-37); ora deixa 
ROSENFIELD, K.; PEREIRA, L. - Um diálogo inspirador no Réquiem a uma Amiga

transparecer a tortura do sofrimento físico que acompanha a morte (RILKE 1996 I: 415 vv. 38-43); ora a partida da morta parece irradiar a mais aguda carência, como se rogasse algo essencial, acuando o poeta que agora se lança em tentativas angustiadas de preencher sua falta e compensá-la (RILKE 1996 I: 415 vv. 46-50):

dass aus dem Kreislauf, der dich schon empfing, die stumme Schwerkraft irgend einer Unruh dich niederzieht zur abgezählten Zeit -:

dies weckt mich nachts oft wie ein Dieb, der einbricht.

Und dürft ich sagen, dass du nur geruhst, dass du aus Großmut kommst, aus Überfülle, weil du so sicher bist, so in dir selbst, dass du herumgehst wie ein Kind, nicht bange vor Örtern, wo man einem etwas tut -: doch nein: du bittest. Dieses geht mir so bis ins Gebein und querrt wie eine Säge. Ein Vorwurf, den du trügest als Gespenst, nachtrügest mir, wenn ich mich nachts zurückzieh in meine Lunge, in die Eingeweide, in meines Herzens letzte ärmste Kammer, ein solcher Vorwurf wäre nicht so grausam, wie dieses Bitten ist. Was bittest du?

Sag, soll ich reisen? Hast du irgendwo ein Ding zurückgelassen, das sich quält und das dir nachwill? Soll ich in ein Land, das du nicht sahst, obwohl es dir verwandt war wie die andre Hälfte deiner Sinne?

Que a muda gravidade de alguma aflição, Para fora do círculo que te acolheu Te empurre pra baixo no tempo mensurado; Isso, como um ladrão, me acorda em plena noite

E eu talvez possa dizer que só concedeste Vir, na tua magnanimidade e plenitude, Porque tu estás tão segura, tão em ti mesma Que vagas feito criança, sem medo algum Do lugar onde um mal é feito contra alguém Mas não: tu rogas. E isso me penetra fundo Dentro dos ossos, me trincha como uma serra, Um reproche que vestes, como a um espectro, Pra me censurar, quando à noite me recolho No meu pulmão, nas minhas entranhas, no último Mais mísero recesso do meu coração, -

Um reproche assim não seria tão cruel Quanto essa súplica. O que é que suplicas.

Diz, devo viajar? Deixaste acaso algo atrás No mundo, que se tortura e quer te seguir? E devo ir a algum país que tu não viste, Mas com o qual tu tens alguma afinidade

Como se fosse parte dos teus sentimentos? (RILKE 1996 I: vv. 29-50)

Mas sempre de novo o poema traz à tona as afinidades dos dois artistas cujo encontro foi menos pessoal do que mediado pela prática artística e pelas "coisas" 
ROSENFIELD, K.; PEREIRA, L. - Um diálogo inspirador no Réquiem a uma Amiga

presentificadas de suas respectivas obras - assim os quadros de naturezas mortas de Paula $^{4}$, com suas flores e frutas coloridas e radiosas, renascem nas palavras do poeta e transubstanciam-se no corpo concreto e vivo da pintora (RILKE 1996 I: 416, 66-87):

Und Früchte will ich kaufen, Früchte, drin

das Land noch einmal ist, bis an den Himmel.

Denn Das verstandest du: die vollen Früchte.

Die legtest du auf Schalen vor dich hin

und wogst mit Farben ihre Schwere auf.

E eu quero

Comprar frutas, frutas, em cujo âmago a terra

Mais uma vez está, vibrando até os céus.

Pois isso compreendeste: as frutas repletas.

$\mathrm{Tu}$ as deitaste sobre cascas na tua frente

E ainda sopesaste seu peso com as cores. (RILKE 1996 I: 416 vv. 66-87)

Em certos momentos, essa intimidade se aproxima quase de núpcias místicas Rilke se identifica e se une à amiga com uma intensidade íntima que talvez explique por que o poeta evitou mencionar o nome de Paula explicitamente.

Para além da dimensão pessoal e afetiva do luto, o Réquiem a uma amiga testemunha também uma importante mudança de estilo que marca as diversas fases da obra de Rilke, evidenciando que o diálogo com artistas plásticos de Worpswede deixou suas marcas na poesia rilkeana 5 . Primeiro, o rumo à Dingwendung, ou seja, a "virada para as coisas" na sua concretude própria (FRICKE; GRUBMÜLLER; MÜLLER 1997: I, 367 s.). A guinada em direção às coisas marca na obra de Rilke o abandono da beleza refinada da Belle Époque e do simbolismo, um despojamento que deixa subsistir do sentido simbólico apenas o que está no próprio objeto, aquilo que se revela na sua própria consistência enigmática ${ }^{6}$.

É notável que o interesse por Worpswede e a descoberta da obra de Paula coincidiram na trajetória de Rilke (quando não foram precedidos por) com um intenso

\footnotetext{
${ }^{4}$ Como a reprodução de imagens requer a aquisição de direitos, recomendamos a consulta do artigo sobre Paula Modersohn-Becker na Wikipaedia / Images.

${ }^{5}$ A pesquisa sobre as relações de Rilke e de sua poesia com as artes plásticas não é um campo de investigação novo, como mostram as sínteses do Rilke-Handbuch de 2013, cujos autores serão citados nesse artigo. Com a exceção da tese de Danilo Chiovatto Serpa (SERPA, 2019), os trabalhos de pesquisadores brasileiros relacionados com artes plásticas não tratam do Réquiem a uma amiga (Paula ModersohnBecker), nem de Worpswede. Por terem datas de publicação posteriores à do Rilke Handbuch que é usado amplamente pelos pesquisadores brasileiros privilegiamos as referências aos autores alemães. No âmbito da temática das artes plásticas merecem menção, entre outros trabalhos, Rios, Rita. Poemas e Pedras. A relação entre a escultura e a poesia partindo de Rodin e Rilke. EDUSP, São Paulo, 2011. Outras teses sobre Rilke e as artes plásticas, porém sem relação com o Réquiem: Costa (2019); Chagas (2019); Bazan (2018). ${ }^{6}$ Uma das obras mais emblemáticas da Dingwendung, que inicia a busca da concretude palpável das coisas, é $A$ Pantera, de 1902. Cf. Müller, 2013: 297; cf. a comparação das traduções brasileiras de $A$ Panthera em Barreto 2020: 118-128.
}

Pandaemonium, São Paulo, v. 24, n. 44, set.-dez. 2021, p. 271-295 
ROSENFIELD, K.; PEREIRA, L. - Um diálogo inspirador no Réquiem a uma Amiga

interesse pelas artes plásticas. Rilke se debruça sobre as obras de pintores e escultores, motivado por quatro questões principais, escreve Winfried Eckel: "Primeiro, a necessidade de clarificar dúvidas existenciais, isto é, perguntas sobre a conduta da boa vida e do trabalho autêntico do artista [... e ele encontrou as respostas] no estudo das obras de Auguste Rodin (1840-1917), Vincent van Gogh (1853-1890) e Paul Cézanne ${ }^{7}$ (18391906)" (ECKEL 2013, RHB 130). O segundo ponto importante é a autodefinição como poeta entre as tradições do passado e os movimentos contemporâneos que apontam para o futuro. Nessa questão da identidade poética chama atenção como Rilke, embora impactado pelos artistas de vanguarda que preparam o caminho para a abstração, manteve suas simpatias até o final da vida no limiar entre as formas figurativas e as abstratas. Em terceiro lugar, sua linguagem poética busca apoio nas metáforas, imagem e todo um “vocabulário do sensível” (ECKEL 2013, RHB 130 s.), como se essa riqueza de coisas tangíveis oferecesse apoio e proteção contra as incertezas do ceticismo ligado à crise da linguagem. E, por último, as idas e voltas entre os princípios das artes plásticas e os da poesia fazem parte da investigação mais geral a respeito da criatividade e da originalidade artísticas. Todos esses interesses estavam em perfeita sintonia com as investigações e ensinamentos que Paula Becker procurava quando veio a Paris pela primeira vez em janeiro de 1900. Não é um acaso que Rilke tenha encontrado Clara Westhoff (sua futura esposa) e Paula Becker no ateliê de Rodin, naquela época em que Paula foi uma das primeiras artistas alemãs a descobrir a obra de Cézanne. Rodin foi um dos primeiros artistas que deixou impacto durável na mente de Rilke já em 1900, influenciando de modo decisivo sua autodefinição como artista. Durante sua segunda estadia em Paris (de setembro de 1905 a julho de 1906), Rilke passou certo tempo na residência de Rodin em Meudon, perto de Paris, e aceitou servir como secretário particular durante alguns meses. O contato pessoal com o escultor forneceu ao poeta impulsos criativos e uma ética de trabalho constante e assíduo - qualidades essas que ficam tangíveis na precisão concreta das metáforas e imagens dos Novos Poemas - e nas exortações à dedicação que o poeta passou para a amiga Paula em Worpswede, quando a pintora passou um período em Paris no início de 1906 (STORCK 2013, RHB, p. 7).

Mas as obras e o modo de vida simples, voltado para o trabalho assíduo que o poeta conheceu na sua convivência com o grupo de Worpswede também forneceu

\footnotetext{
${ }^{7}$ Rilke escreveu textos importantes sobre Rodin e Cézanne nos anos 1902-1907; cf. os textos sobre Rodin in: Rilke 1996 2: 403-451; as Cartas sobre Cézanne (RILKE 1996 2: 594-635) que evidenciam a intensidade da investigação rilkeana da linguagem pictórica e escultural.
}

Pandaemonium, São Paulo, v. 24, n. 44, set.-dez. 2021, p. 271-295 
ROSENFIELD, K.; PEREIRA, L. - Um diálogo inspirador no Réquiem a uma Amiga

impulsos relevantes para as quatro buscas listadas por Winfried Eckel. O primitivismo de Worpswede e também a arte e a personalidade de Paula podem ter lhe fornecido certa serenidade capaz de estancar pelo menos em parte o ceticismo generalizado dessa era de galopante transformação industrial, tecnológica e urbana do mundo, uma urbanização que trouxe consigo um repentino déficit de certezas, crenças e tradições. Não se pode esquecer o contexto austríaco do qual Rilke emerge: a cultura intelectual vienense foi um dos berços do ceticismo linguístico e resultou em algumas das mais vigorosas formulações filosóficas, poéticas e crítico-teóricas da crise da linguagem. Agitando as investigações artísticas e poetológicas que se debatem com o impasse do simbolismo, essa crise leva o amigo de Rilke, Hugo von Hofmannsthal (1874-1929), a dramatizar essa crise das formas de expressão esvaziadas pela tradição na famosa "Carta de Lord Chandos", de 1902 (HOFMANNSTHAL 2009: 89-97).

O Réquiem a uma Amiga representa, entre muitas coisas mais, também um momento de recolhimento e reflexão sobre o alcance da combinação híbrida das diversas formas de expressão - a visual e a verbal - como resposta às "distorções" e ao "fracasso da palavra na grande crise do mundo", como Peter Por formula no seu estudo dos dois Réquiens de 1908 (PoR 1998: 55 s.). A concretude das coisas nos quadros de Paula aponta para um além do figurativo, e, apesar de sua plasticidade tangível, para algo mais etéreo, desconhecido e incognoscível que emana das coisas e que nega ao espectador a satisfação da plena compreensão. Rilke parece lamentar ter sido abandonado justo por essa amiga: ela que soube trilhar o novo caminho rumo às coisas e às estranhezas incognoscíveis dos objetos e das criaturas, e que teve a delicadeza de renunciar a qualquer pretensão desmedida de recolhê-los plenamente na forma de sua arte. O Réquiem honra Paula pela plenitude desse despojamento. Em suas pinturas, identificamos não apenas a tremenda coragem de acolher a face desconhecida dos objetos fora de nós mesmos, como de encarar o objeto desconhecido do próprio corpo - a artista foi a primeira mulher a se autorepresentar nua, dando a contemplar a estranheza desconcertante do próprio corpo como grávida. O poeta reconhece a genialidade pioneira da amiga nos versos que igualam as naturezas mortas com os autorretratos; as frutas descascadas deitam por sobre suas "vestes" como os nus e revelam a verdade "coisal" que o ser humano compartilha com os objetos. O carinho tosco das telas oferece a alma no seu invólucro "primitivo", mas é 
ROSENFIELD, K.; PEREIRA, L. - Um diálogo inspirador no Réquiem a uma Amiga

justo esse suporte rude - uma rudeza que a abstração sublinha - que intensifica o olhar animado e sua dimensão intelectual e espiritual:

E viste a ti mesma por fim como uma fruta,

Te colheste pra fora de tuas roupas, te

Puseste ao espelho e te deixaste adentrá-lo

Até alcançar o olhar que ali restou, imenso,

E não disse: isso sou eu; mas: isso é. (RILKE 1996 II: 416 vv. 74-84)

Rilke escreveu ainda um segundo réquiem em 1908: além do Réquiem a uma amiga, o segundo, escrito nos dias seguintes, lamenta o suicídio de um poeta promissor, do jovem Wolf Graf von Kalckreuth (1887-1906), que tirou sua vida aos vinte anos. Ambos merecem destaque no conjunto da obra de Rilke, pois evidenciam o impacto que a observação das técnicas de artistas plásticos imprimiu sobre sua poética. Cabe lembrar que foi Paula quem atraiu a atenção de Clara Westhoff e Rilke para Cézanne, em 1900, e o poeta escreve eloquentes cartas sobre a obra do pintor francês em 1907. É no olhar da pintora, portanto, que o Réquiem se inspira, e a poética dos Dingedichte também parece emular os princípios da técnica visual de Paula Modersohn-Becker, transferindo-os para o domínio da literatura. Não é simples metáfora quando Rilke diz, depois de evocar a intensa presença das coisas e dos corpos nos quadros de Paula:

E ao final teu olhar estava tão sem zelos,

Tão despossuído, tão pleno de humildade,

Que já nem desejava a si mesmo: sagrado.

E é assim que quero te guardar, no teu pairar

Em pé dentro do espelho, bem no fundo e longe

De tudo. (RILKE 1996 I: 416 vv. 86-90)

Como já mencionado, Rilke se debruçou intensamente sobre as obras de Paula durante o Natal de 1905. Um ano e meio depois, entre julho e novembro de 1907, ele escreveu as Cartas sobre Cézanne (RILKE 1996 IV: 594-636), nas quais define a tarefa do artista que Paula já lhe inspirara: essa consistia em tornar-se o objeto que o artista vê, ao mesmo tempo que é olhado e invocado pelo objeto; o artista precisa descrever e trabalhar para "estar-disponível como coisa concreta e factual" (Vorhandensein als Tatsache, RILKE 1996 IV: 622 s.).

É tentador pensar que a intensa contemplação das obras de artistas como Rodin, Paula Modersohn-Becker, Van Gogh e Cézanne, e a reflexão sobre seus princípios 
ROSENFIELD, K.; PEREIRA, L. - Um diálogo inspirador no Réquiem a uma Amiga

criativos podem ter preparado a sensibilidade de Rilke para o encontro com a estranheza da poesia de Friedrich Hölderlin (1770-1843) e com as revolucionárias técnicas tradutórias desse poeta esquecido, que se inspirou em Píndaro quando ousou fazer experimentos pioneiros com imagens e choques de imagens (HOFMANN 1995: 74-103). Hölderlin deve sua redescoberta ao jovem filólogo Norbert von Hellingrath (1888-1916), que se deparou com papeis e manuscritos do poeta na biblioteca de Stuttgart, em 1909. As palestras de Hellingrath em München em 1915 (RILKE 1996 II: 883) levam Rilke a se familiarizar com as bizarras traduções hölderlinianas de Píndaro e a compreender técnicas poéticas gregas que o classicismo de Weimar rejeitara, por ferirem a visão da suposta elegância clássica. A partir do trabalho de Hellingrath, a filologia começa a apreciar de novo as "harmonias ásperas", que trabalha com efeitos criados pelo choque de imagens (contrastes e dissonâncias criados pela juxtaposição de representações visuais e de imagens verbais) - um primeiro passo para além das convenções que buscavam a suavidade lisa de modelos habituais, como a canção popular (Volkslied) (HELLINGRATH 1911: $1-5)^{8}$.

Por intermédio das conferências e dos ensaios de Hellingrath sobre as traduções hölderlinianas de Píndaro, Rilke se debruça sobre as virtudes da "harmonia austera ou

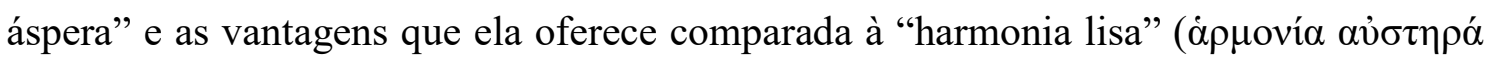

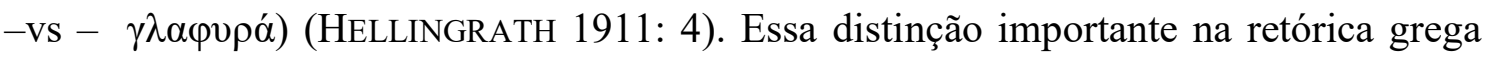
atribui à harmonia áspera a função de tornar a leitura mais lenta, difícil e reflexiva, atraindo a atenção para as associações diversas entre palavras e imagens isoladas nos versos, uma técnica que resulta, por exemplo, nos versos mais densos e profundos de Píndaro. A técnica não deixa de ter analogias com a carga expressiva das técnicas visuais de Paula. Como na composição visual (primitiva, elementar), também a "harmonia áspera" introduz uma dureza rugosa que parece perturbar a compreensão convencional do sentido; mas o nexo semântico mais difícil (áspero) entre os elementos do poema

\footnotetext{
${ }^{8}$ Friedrich Norbert Theodor von Hellingrath descobriu Friedrich Hölderlin durante seus estudos de filologia grega e alemã na Universidade de Munique, em 1906, com os professores Otto Crusius e Friedrich von der Leyen. O entusiasmo de Hellingrath pelo poeta ocasionou a redescoberta, na biblioteca de Stuttgart (novembro de 1909), dos últimos hinos de Friedrich Hölderlin e das traduções hölderlinianas de Píndaro. O amigo Karl Wolfskehl, que fazia parte do círculo em torno de Stefan George, passou as transcrições feitas por Hellingrath a George, que propós publicá-las pela editora Blätter für die Kunst (da qual de fato saíram, já em fevereiro de 1910). O sucesso do poeta esquecido foi imediato e, em 1912, Hellingrath começou a publicar uma edição das obras de Hölderlin, com seus amigos Edgar Salin e Wolfgang Heyer (o primeiro volume saiu em 1913), terminando ao mesmo tempo sua tese sobre as traduções hölderlinianas de Píndaro. Os escritos de Hellingrath se encontram no Arquivo Hölderlin, na Württembergische Landesbibliothek (HELLINGRATH 1911: 1-25).
} 
ROSENFIELD, K.; PEREIRA, L. - Um diálogo inspirador no Réquiem a uma Amiga

apenas suspende a compreensão corriqueira. Pausas e hiatos bruscos ou insuficientes elos sintáticos isolam as palavras como esculturas - numa solidão que deixa emergir outros nexos e associações. Rilke modula essa técnica altamente reflexiva na sua poesia tardia. Mas, bem antes de tomar conhecimento de Hellingrath e de Hölderlin, a contemplação das obras da jovem e ousada Paula Modersohn-Becker já instilava o germe da abstração na imaginação rilkeana. A sobriedade mais dura, abstrata e altamente reflexiva de sua arte tardia iria desabrochar apenas mais tarde. Por enquanto, o poeta se inspira nas imagens ingênuas e nos sabores inusitados dos volumes e das cores de Paula. Mas a contemplação e a reflexão já preparam sua sensibilidade para o despojamento com que ele abandonaria em breve o estilo suave do Jugendstil. Suas Elegias não temem os hiatos e as condensações do tecido habitual da linguagem, que frustram a compreensão imediata. Ele se apropriaria da parataxe hölderliniana que abre a sensibilidade para a contemplação das palavras singulares: destacadas como figuras ou esculturas isoladas - como que à espera de um outro contexto maior e mais significativo, expostas à força significante da qual emergiram.

$* * *$

As reflexões que Rilke teceu, na introdução ao seu pequeno livro de 1902 sobre Worpswede (RILKE 1996 IV: 307-326), em torno do novo gênero "primitivista", são apenas o início de seu trabalho de absorção das técnicas visuais na poesia. Alguns dos aspectos que aborda aí valem ser lembrados também para a obra de Paula - por exemplo, quando diz dos pintores de Worpswede que não vivem com a população naquele lugar rústico, mas por assim dizer:

[...] estão defronte deles (gegenüberstehen), como estão de frente para as árvores e para todas as coisas que crescem e se movem, rodeadas pelo ar úmido e lamacento. Eles vêm de longe. E apertam esses seres, que não são seus semelhantes, contra essa paisagem; e isso não é uma violência. Para isso basta a força de uma criança, -e Runge escreveu: "Temos que nos tornar crianças, se quisermos alcançar o melhor." Eles alvejam o melhor e se tornaram crianças. Eles veem tudo envolto no mesmo sopro, seres humanos e coisas. (RILKE 1996 IV: 319).

Em outras palavras: a intensa observação das coisas coloca o artista no âmago concreto do mundo ao redor, e deixa sua alteridade incomunicável pairar como um halo, como que no horizonte apenas. O reconhecimento e a familiaridade com as coisas menos animadas - árvores, pedras, bosques, pradarias - podem assim nos surpreender também 
ROSENFIELD, K.; PEREIRA, L. - Um diálogo inspirador no Réquiem a uma Amiga

com sua inquietante estranheza. $\mathrm{O}$ que distingue os quadros de Paula não é apenas a concretude, mas o fato que neles vislumbramos, de repente, a avassaladora estranheza das linguagens que mobilizamos, em vão, para estarmos mais próximos das pessoas e das coisas, e esse vazio que espera o artista no âmago de toda representação não deixa de ser uma espécie de morte. É esse traço da inquietante familiaridade-e-estranheza que Paula Modersohn-Becker intensificou na sua peculiar modulação da pintura de paisagem reduzida a um mesmo plano no qual as figuras (humanas, animais e outras) se fundem e quase se dissolvem. E embora ela não seja conhecida como pintora de paisagens, modulou, a seu modo, um dos traços da pintura de paisagem que Rilke comentou em 1902. Na introdução ao seu livro sobre Worpswede, ele diz que, diante de um quadro com uma paisagem pintada, o pintor (ou o espectador) está “exposto ao estranho, ao que não possui afinidade conosco, ao inconcebível". E, no seguinte parágrafo, ele resume suas ponderações com essas palavras eloquentes, que têm sua validade também e sobretudo para as telas de Paula Modersohn-Becker:

Pois é preciso admitir: a paisagem é para nós algo estranho; estamos terrivelmente sós no meio de árvores em flor, e entre riachos correndo em volta. A sós com um humano morto não estamos de longe tão expostos como quando sozinhos com as árvores. Pois por mais que seja enigmática a morte, mais enigmática ainda é a vida que não é nossa vida, que não compartilha dos nossos anseios e que festeja suas próprias festas, como que sem sequer nos ver, festas que observamos com certo cismar e constrangimento, como hóspedes que chegaram ao acaso e falam uma língua diversa. (RILKE 1996 IV: 308).

O que Rilke elogia e comemora com seu Réquiem é a coragem-de-artista de Paula Modersohn-Becker de se expor ao avesso inquietante e assombroso que nos aguarda na imensidão aberta dos rostos e das coisas, dos corpos e paisagens - quando seu aspecto familiar de repente se esvai e deixa transparecer uma inquietante e insuspeitada estranheza: Das weite Land, a terra vasta dos assombros das almas e da solidão dos sentimentos que preferimos desconhecer na vida cotidiana (SCHNITZLER 1961). A coragem do poeta consiste em saber que nenhuma palavra consegue totalmente costurar esse hiato e continuar cerzindo suas tramas poéticas, confiando na palavra, apesar dos irremediáveis desencontros da palavra e da coisa, que chega ao seu paroxismo quando falamos da morte da pessoa amada, tentando trazê-la de volta simbolicamente. Rilke deu o tom e viabilizou a compreensão intuitiva para a sensibilidade literária - inclusive na prosa, como por exemplo na peça mencionada de Schnitzler, que dramatiza a tremenda solidão de cada indivíduo, mesmo no amor e sobretudo no meio da mais intensa e alegre sociabilidade. Esse drama foi escrito em 1911, dois anos após o Réquiem, e uma década depois das reflexões de Rilke sobre a pintura de paisagem.

Pandaemonium, São Paulo, v. 24, n. 44, set.-dez. 2021, p. 271-295 
ROSENFIELD, K.; PEREIRA, L. - Um diálogo inspirador no Réquiem a uma Amiga

É impressionante o salto qualitativo dos seus dois grandes réquiens de 1908, quando comparados com um outro réquiem de 1900, intitulado simplesmente "Réquiem" (RILKE 1996 I: 341-346), esse último ocasionado pela morte de Gretel Kottmeyers, uma amiga da esposa Clara Westhoff. Esse longo poema começa com dois versos que procuram transformar a perda em um "a mais", o vazio da amiga que falta em presença "Faz uma hora que existe uma coisa a mais, algo mais / no mundo. Algo mais em torno de uma coroa [fúnebre].” (RILKE 1996 I: 341); seguem sequências ou fragmentos que têm o caráter de uma rememoração caleidoscópica de certos episódios da vida de Gretl e encaixes de diálogos com a morta que buscam explicar as causas de sua morte: “Gretl, do começo / teu destino foi de morrer jovem, / de morrer loira. [...].” Apesar das muitas belas imagens, emana desse poema um tom didático e distante, que dá a essa coroa de palavras poéticas de luto o ar convencional da poesia de ocasião. Isso muda completamente oito anos depois, no início de novembro de 1908, quando Rilke escreve seu segundo Requiem für eine Freundin, para homenagear, agora com intensidade e densidade muito maiores, Paula Modersohn-Becker, cuja morte ocorrera no ano anterior (RILKE 1996 IV: 414-421), e, o terceiro Requiem für Wolf Graf von Kalckreuth, (RILKE 1996 IV: 422-426), que chora o suicídio desse jovem poeta aos vinte anos.

Esses dois extensos poemas mostram uma transformação qualitativa notável da arte rilkeana, e o Réquiem para uma amiga já prepara, de alguma maneira, o campo para aquele salto que distingue a obra tardia, verificado nos Sonetos a Orfeu (1922, RILKE 1995 II: 237-272) e nas Elegias (RILKE 1996 II: 199-234), cuja composição ocuparia o poeta até a sua morte, em 1926. Os Sonetos a Orfeu dissolvem a forma tradicional do soneto em canto, e talvez seja possível dizer do Réquiem para Paula o que o próprio poeta disse, certa vez, acerca da liberdade que lhe permitiu alçar a velha forma do soneto para um patamar totalmente diverso: os poemas que receberam esse nome "seriam a coisa mais livre e solta que ainda podemos aceitar para essa forma que em geral é tão tranquila e estável." Pois o poeta colocou-se a tarefa “de flexionar o soneto, de alçá-lo, como quando carregamos algo precioso em plena corrida, sem destruí-lo" (RILKE 1996 II: 719). É esse gesto veloz e delicado que distingue também o Réquiem a uma amiga.

Pandaemonium, São Paulo, v. 24, n. 44, set.-dez. 2021, p. 271-295 
ROSENFIELD, K.; PEREIRA, L. - Um diálogo inspirador no Réquiem a uma Amiga

Juliana Perez escreveu algumas belas páginas sobre a "passagem da abstração transcendente à objetividade apaixonada" (PEREz 2017) que Rilke realiza nos seus "Novos poemas", de 1907. E ela cita uma declaração de Rilke sobre sua relação com a natureza que tanto deve à convivência com os pintores de paisagem como Paula e os demais Worpswedeanos: “... a natureza era para mim, então [no Livro das Horas], um ensejo geral, uma evocação, um instrumento em cujas cordas minhas mãos se reconheciam; eu ainda não sentava diante dela; me deixava levar pela alma que dela emanava" (RILKE 2001: 63). Essa declaração marca o auge da busca intensa das coisas na sua concretude visível. Mas já no ano seguinte, o Réquiem marca, como já frisamos, a transição para mais uma nova fase, que aprofunda a dimensão reflexiva da poesia e a exploração daquele horizonte das coisas invisíveis, estranhas e inquietantes que ressoa também na natureza e nas coisas concretas.

Nesse sentido, gostaríamos de terminar esse ensaio com algumas considerações sobre o papel que o réquiem preencheu nessa transição de Rilke como mediador entre o trabalho de luto e a reflexão sobre a tarefa existencial do poeta. O impulso que move um poeta ou um compositor a escrever um réquiem é em geral a vontade de conferir uma dimensão ritual ao luto ou a necessidade de dar um aspecto litúrgico à comemoração de uma morte. No caso do Réquiem a uma Amiga, a forma, os temas do diálogo e a extensão desse poema deixam entrever o abalo duradouro que a morte inesperada da amiga provocou. Com a ambivalência típica do luto, os versos tanto convocam o espírito da morta a retornar, como pedem que se aquiete no além; uma extensa ruminação coloca o alter-ego lírico de Rilke frente a frente com a morta, debatendo-se com sua estranha ausência-presente, que imprime a esse diálogo seus movimentos sinuosos. Há momentos em que as súplicas do "Eu" lírico assumem a posição de Orfeu, o poeta-cantor proibido de ver o semblante da pessoa amada emergindo do Hades - um mito que Rilke já abordou em 1904-5, com o poema Orpheus. Euridike. Hermes (RILKE, 1, 500-503). Através da figura mítica de Orfeu, Rilke reflete sobre o drama do trabalho poético, e em particular com o paradoxo da criação que busca tornar presente a concretude das coisas e de sua vida, porém pode cumprir essa tarefa apenas na medida em que renuncia a possuí-las. Orfeu desafiou o Hades, determinado em trazer de volta a esposa Eurídice, seus cantos já conseguiram abrir os grilhões do mundo dos mortos, quase deixando a defunta voltar para o mundo dos vivos. Mas no último momento, Orfeu não se conteve: cedeu à tentação de voltar o olhar para trás, ávido de abraçar a mulher com os olhos - apenas para vê-la desvanecer de novo, sua sombra confundindo-se com as névoas do além.

Pandaemonium, São Paulo, v. 24, n. 44, set.-dez. 2021, p. 271-295 
ROSENFIELD, K.; PEREIRA, L. - Um diálogo inspirador no Réquiem a uma Amiga

O Réquiem a uma Amiga gravita em torno desse mesmo paradoxo contido no mito de Orfeu, no qual se condensa a ética da renúncia e da incompatibilidade da missão do artista à dedicação a uma amante ou à vida como tal - uma crença aflora nos aforismos de um texto de 1921, O Testamento (RILKE, 4, 722). No mesmo sentido, o Réquiem marca ao mesmo tempo o ponto culminante da objetividade que busca estar defronte às coisas e à vida, como também anuncia a poesia densa, reflexiva e voltada para o inominável e o invisível que caracteriza o ciclo bem mais tardio dos Sonetos a Orfeu, de 1922-1926 (RILKE, 2, 720 s.) e das Elegias.

Já nos primeiros versos desenha-se o desafio do poeta-cantor, alter-ego de Orfeu, que precisa cumprir sua missão. Ela consiste em salvar os seres efêmeros mais preciosos do não-ser, subtraindo-as ao esquecimento e resguardando-as do vazio existencial cuja forma mais compacta é a morte física. O problema que se coloca é de como cumprir essa tarefa sem cometer o erro de Orfeu :

Ich habe Tote, und ich ließ sie hin und war erstaunt, sie so getrost zu sehn, so rasch zuhaus im Totsein, so gerecht, so anders als ihr Ruf. Nur du, du kehrst zurück; du streifst mich, du gehst um, du willst an etwas stoßen, dass es klingt von dir und dich verrät $[\ldots]$.

Eu tenho os meus mortos e os deixei partir,

E espantou-me vê-los tão contentes, tão rápido

Ambientados no âmbito da morte, tão

Justos, tão distintos de sua fama. Tu, só

$\mathrm{Tu}$ voltas. Tu me roças em tua ronda, queres

Bater em algo para que tlinte ao teu toque

Traindo a tua presença. (RILKE 1996, I, 414)

Os versos expõem de modo muito claro a semelhança do trabalho paradoxal do poeta e do enlutado: ambos se encontram assediados pela memória, como se a morta retornasse e os assombrasse como um espectro - quando sua tarefa consiste em cumprir o gesto paradoxal de tornar-presente a pessoa perdida ao deixa-la ir. É nítido que o "Eu" lírico que dialoga com a morta como se estivesse fisicamente presente reluta contra a atração perigosa que emana da morta ou da morte como tal: como Orfeu tentado a voltar o olhar para a imagem da esposa, o "Eu" de Rilke sente a tentação do apego sentimental ao que está irremediavelmente perdido, e interpela a amiga para que deixe de retornar na sua memória: 
ROSENFIELD, K.; PEREIRA, L. - Um diálogo inspirador no Réquiem a uma Amiga

O nimm mir nicht, was ich

langsam erlern. Ich habe recht; du irrst

wenn du gerührt zu irgend einem Ding

ein Heimweh hast.

Oh, não tires de mim

Aquilo que aprendo aos poucos. Eu estou certo

Que erras quando, movida por alguma coisa,

Sentes falta de casa. (RILKE 1996 I: v. 414)

A súplica "Oh, não tires de mim / Aquilo que aprendo aos poucos" capta a complexidade do fenômeno do luto, que abala Rilke como pessoa e como poeta. Ao nível psicológico, a pessoa enfrenta o problema afetivo da perda que pode provocar o apego reativo e excessivo ao morto. Esse apego pode resultar em certos casos no sofrimento neurótico da obsessiva repetição da rememoração lutuoso - uma síndrome que Freud abordará na década seguinte nos seus famosos ensaios sobre "Luto e Melancolia" e no seu estudo sobre as neuroses traumáticas dos veteranos da Primeira Guerra Mundial (FrEUD 1981, X, 428-46 e XII, 321-4). O fracasso do luto, muito estudado na esteira dos trabalhos pioneiros de Freud, arrisca transformar o gesto piedoso que honra a memória dos falecidos, em rituais obsessivos de apropriação que buscam reaver algo (impossível) do passado. E os versos de Rilke antecipam as intuições freudianas vendo a síndrome do apego obsessivo ao passado no plano da cultura.

Ao nível poético, o "Eu" lírico de Rilke teme não apenas se assombrar psicologicamente pelo retorno da amiga morta, ele teme ao mesmo tempo o análogo artístico do impossível luto: as atitudes saudosistas (Heimweh ${ }^{9}$ ) que sonham com o possível retorno a um centro telúrico na natureza ou as nostalgias estéticas que insistem na redundância e no apego às belezas do passado. Com a desconfiança do saudosismo, Heimweh, Rilke talvez tenha articulado suas reticências com certos pendores nostálgicos dos artistas de Worpswede Alguns deles se inspiraram numa doutrina que não estava de todo livre do saudosismo da terra, que preparou a nostalgia de comunidade do Volk que encontramos com força na obra de Julius Langbehn ${ }^{10}$. A preocupação pode ter passado pela mente de Rilke, mas o pendor telúrico não é o perigo principal para ele. Se houver

\footnotetext{
${ }^{9}$ As nostalgias do acolhimento familiar em casa (Heimweh) tem no Brasil sua correspondência nas saudades da terra. Esse sentimento lânguido tornou-se um topos desde o famoso verso de Gonçalves Dias "Minha terra tem palmeiras, onde canta o sabiá." Mas tanto na Alemanha, como no Brasil, surgiram vozes de poetas e intelectuais criticando o esvaziamento desse topos e sua transformação em clichés (cf. PRADO 1962).

${ }^{10}$ Seu livro Rembrandt como Educador será em breve elevado a uma das Bíblias da ideologia germânica (STERN 1974: 116-37), fornecendo a partir dos anos 1930 uma base ideológica para a crescente hostilidade aos movimentos modernos e às vanguardas artísticas.
}

Pandaemonium, São Paulo, v. 24, n. 44, set.-dez. 2021, p. 271-295 
ROSENFIELD, K.; PEREIRA, L. - Um diálogo inspirador no Réquiem a uma Amiga

um perigo poético para ele, esse se encontra mais no domínio do apego esteticista: aos olhos dos escritores e críticos mais jovens, a poesia de Rilke sempre foi suspeita, quando não abertamente ridicularizada como kitsch - e isso por diversos críticos, entre eles Bertold Brecht e Walter Benjamin ${ }^{11}$ (BENJAMIN 1980, GS, IV, 1, 2, 453 s.).

No entanto, críticos da geração mais velha, os contemporâneos de Rilke, souberam apreciar a luta desse poeta para superar as suavidades do Jugenstil e firmar sua voz na própria precariedade dos tempos modernos. Robert Musil, por exemplo, se opôs à panfletária condenação, elogiando a trajetória de Rilke como uma luta grandiosa não só com as próprias fraquezas, mas com as fraquezas da (falta de) tradição alemã (MUSIL 1978, KP, 1237 ss.). Na perspectiva de Musil, podemos interpretar o frêmito de inquietação nos versos desse Réquiem a uma Amiga como o motor de reflexões - aqui ainda embrionárias - sobre a missão poética que depende de uma relação adequada, e de uma recriação da tradição que desmantela os modelos e as convenções, trilhando novos caminhos, mais contemporâneos, para a sensibilidade. O nítido rechaço do "Heimweh" (saudades da terra, nostalgia de casa) evidencia o receio do poeta de deixar-se contaminar pela sentimentalidade e do Kitsch, e de todo o culto do patrimônio histórico que constituía o cerne do antimodernismo de Langbehn.

Não é impossível que Rilke, no meio de sua admiração pelos Worpswedianos e por Paula Modersohn-Becker, temesse também o potencial conservador e convencional dos artistas de Worpswede - cujas simpatias pelas ideias de Julius Langbehn são bem conhecidas. Fritz Stern analisa em detalhe o papel de Julius Langbehn na "ascensão da ideologia germânica", sua pregação de práticas culturais calcadas sobre os modelos míticos e históricos da cultura germânica, a heroicização do Volk e a demonização de todas as formas de sociabilidade modernas, cosmopolitas, republicanas e internacionais (STERN 1974: 97-180).

Na obra madura de Rilke, vemos antes um movimento contrário a esse pendor de "re-mitização" que hoje tem conotações tão pejorativas, em particular na literatura alemã. Ulrich Füllhorn, no seu comentário dos Sonetos a Orfeu (FÜLLHORN, RILKE 1996, 2720 s.), aborda a resistência de Rilke a essa tendência; seus sonetos desmantelam, abstraem o

\footnotetext{
${ }^{11}$ Benjamin despacha Rilke como artesão de bijuterias, cuja morte deve servir como advertência contra o mau gosto de um certo público alemão da Belle Époque e do Jugendstil: "A poesia de Rilke é tão carregada com todas as fraquezas, todos os vícios de sua geração, que quase temos licença de sentir alívio com a morte dessa testemunha, do companheiro daquele opróbrio adocicado. Por essa razão, sua poesia deveria calar." (BENJAMIN 1980, GS, IV, 1, 2, 453).
}

Pandaemonium, São Paulo, v. 24, n. 44, set.-dez. 2021, p. 271-295 
ROSENFIELD, K.; PEREIRA, L. - Um diálogo inspirador no Réquiem a uma Amiga

mito e recriam as figuras míticas à luz da experiência contemporânea. Esse trabalho de abstrair já começou no Réquiem a uma Amiga, no duplo movimento de busca da presença tangível e do rechaço do apego à concretude física: na renúncia à gratificação da mera reprodução do semblante que caracteriza a redundância, o já-visto do Kitsch. Winfried Eckel chega a uma avaliação semelhante no seu estudo dos dois Réquiens; pondera que o poeta permaneceu numa oscilação contraditória entre a evocação do visível e do tangível na linguagem pictórica de Paula, embora sua própria linguagem já estivesse para além do apego às coisas concretas, aproximando-se, com a evocação de dois artistas mortos, da tensão para o inominável e o invisível que caracteriza a última fase da obra, a das Elegias. (ECKEL 2013, RHB, 132). De fato, é notável como Rilke elogia as cores e a plasticidade dos quadros de Paula, ao mesmo tempo que o poema como um todo aponta para algo muito menos concreto, algo que está além das coisas pintadas - a força, os gestos, o modo de ser dessa pintora. Assim, esse diálogo se debate com o paradoxo da existência de Paula - a artista plena e decidida, que praticou, como Rilke, a abnegação artística e a renúncia a uma vida normal de esposa e mãe, mas que no meio da mais promissora carreira, retornou a Worpswede e faleceu no leito do parto.

\section{Requiem für eine Freundin}

Geschrieben am 31. Oktober, 1. und 2. November 1908 in Paris.

Ich habe Tote, und ich ließ sie hin und war erstaunt, sie so getrost zu sehn, so rasch zuhaus im Totsein, so gerecht, so anders als ihr Ruf. Nur du, du kehrst zurück; du streifst mich, du gehst um, du willst an etwas stoßen, dass es klingt von dir und dich verrät. $\mathrm{O}$ nimm mir nicht, was ich langsam erlern. Ich habe recht; du irrst wenn du gerührt zu irgend einem Ding ein Heimweh hast. Wir wandeln dieses um; es ist nicht hier, wir spiegeln es herein aus unserm Sein, sobald wir es erkennen.

Ich glaubte dich viel weiter. Mich verwirrts, dass $d u$ gerade irrst und kommst, die mehr verwandelt hat als irgend eine Frau. Dass wir erschraken, da du starbst, nein, dass dein starker Tod uns dunkel unterbrach, das Bisdahin abreißend vom Seither: das geht uns an; das einzuordnen wird die Arbeit sein, die wir mit allem tun. Doch dass du selbst erschrakst und auch noch jetzt den Schrecken hast, wo Schrecken nicht mehr gilt; dass du von deiner Ewigkeit ein Stück
Réquiem a uma amiga

(Paris, 31 de Outubro - 2 de Novembro, 1908)

[Escrito em memória da pintora Paula ModersohnBecker (1876-1907)]

Eu tenho os meus mortos e os deixei partir, E espantou-me vê-los tão contentes, tão rápido Ambientados no âmbito da morte, tão Justos, tão distintos de sua fama. Tu, só Tu voltas. Tu me roças em tua ronda, queres Bater em algo para que tlinte ao teu toque Traindo a tua presença. Oh, não tires de mim Aquilo que aprendo aos poucos. Eu estou certo Que erras quando, movida por alguma coisa, Sentes falta de casa. Isso transformamos, Não está aqui. Nós o espelhamos do dentro Fundo de nosso ser, tão logo o divisamos.

$\mathrm{Eu}$ te pensei bem mais à frente. E me transtorna Que justo $t u$ vagues e voltes, tu que mais Do que qualquer outra mulher transfiguraste. Que foi pra nós um susto a tua morte, não, que Tua grave morte, sombria, nos surpreendeu Arrebatando o até-então do desde-então: Isso nos concerne; dar-lhe ordem há de ser O ofício que fazemos com tudo o que existe. Mas que $t u$ tenhas te assustado e ainda sintas Agora o horror onde o horror não cabe mais, Que tu percas parte de tua eternidade 
ROSENFIELD, K.; PEREIRA, L. - Um diálogo inspirador no Réquiem a uma Amiga

verlierst und hier hereintrittst, Freundin, hier, wo alles noch nicht ist; dass du zerstreut, zum ersten Mal im All zerstreut und halb, den Aufgang der unendlichen Naturen nicht so ergriffst wie hier ein jedes Ding; dass aus dem Kreislauf, der dich schon empfing, die stumme Schwerkraft irgend einer Unruh dich niederzieht zur abgezählten Zeit -: dies weckt mich nachts oft wie ein Dieb, der einbricht. Und dürft ich sagen, dass du nur geruhst, dass du aus Großmut kommst, aus Überfülle, weil du so sicher bist, so in dir selbst, dass du herumgehst wie ein Kind, nicht bange vor Örtern, wo man einem etwas tut -: doch nein: du bittest. Dieses geht mir so bis ins Gebein und querrt wie eine Säge. Ein Vorwurf, den du trügest als Gespenst, nachtrügest mir, wenn ich mich nachts zurückzieh in meine Lunge, in die Eingeweide, in meines Herzens letzte ärmste Kammer, ein solcher Vorwurf wäre nicht so grausam, wie dieses Bitten ist. Was bittest du?

Sag, soll ich reisen? Hast du irgendwo ein Ding zurückgelassen, das sich quält und das dir nachwill? Soll ich in ein Land, das du nicht sahst, obwohl es dir verwandt war wie die andre Hälfte deiner Sinne?

Ich will auf seinen Flüssen fahren, will an Land gehn und nach alten Sitten fragen, will mit den Frauen in den Türen sprechen und zusehn, wenn sie ihre Kinder rufen. Ich will mir merken, wie sie dort die Landschaft umnehmen draußen bei der alten Arbeit der Wiesen und der Felder; will begehren, vor ihren König hingeführt zu sein, und will die Priester durch Bestechung reizen, dass sie mich legen vor das stärkste Standbild und fortgehn und die Tempeltore schließen. Dann aber will ich, wenn ich vieles weiß, einfach die Tiere anschaun, dass ein Etwas von ihrer Wendung mir in die Gelenke herübergleitet; will ein kurzes Dasein in ihren Augen haben, die mich halten und langsam lassen, ruhig, ohne Urteil. Ich will mir von den Gärtnern viele Blumen hersagen lassen, dass ich in den Scherben der schönen Eigennamen einen Rest herüberbringe von den hundert Düften. Und Früchte will ich kaufen, Früchte, drin das Land noch einmal ist, bis an den Himmel.

Denn Das verstandest du: die vollen Früchte. Die legtest du auf Schalen vor dich hin und wogst mit Farben ihre Schwere auf. Und so wie Früchte sahst du auch die Fraun und sahst die Kinder so, von innen her getrieben in die Formen ihres Daseins. Und sahst dich selbst zuletzt wie eine Frucht, nahmst dich heraus aus deinen Kleidern, trugst dich vor den Spiegel, ließest dich hinein bis auf dein Schauen; das blieb groß davor
E que tu ingresses aqui, amiga, aqui onde Nada ainda existe; que tu, dispersada, pela Primeira vez no cosmo desfeita e partida, Não tenhas colhido, como o fizeste aqui Com tudo, a emergência das forças infinitas; Que a muda gravidade de alguma aflição, Para fora do círculo que te acolheu

Te empurre pra baixo no tempo mensurado; Isso, como um ladrão, me acorda em plena noite E eu talvez possa dizer que só concedeste Vir, na tua magnanimidade e plenitude, Porque tu estás tão segura, tão em ti mesma Que vagas feito criança, sem medo algum Do lugar onde um mal é feito contra alguém Mas não: tu rogas. E isso me penetra fundo Dentro dos ossos, me trincha como uma serra, Um reproche que vestes, como a um espectro, Pra me censurar, quando à noite me recolho No meu pulmão, nas minhas entranhas, no último Mais mísero recesso do meu coração, Um reproche assim não seria tão cruel Quanto essa súplica. O que é que suplicas. Diz, Devo viajar? Deixaste acaso algo atrás No mundo, que se tortura e quer te seguir? E devo ir a algum país que tu não viste, Mas com o qual tu tens alguma afinidade Como se fosse parte dos teus sentimentos? Eu quero navegar seus rios, quero aportar Em terra e indagar sobre os velhos costumes; Conversar co'as mulheres nos umbrais das portas E vê-las, contemplá-las quando chamam os filhos. $\mathrm{E}$ anotar na memória como elas modelam

A paisagem ali com a ancestral labuta Dos campos e lavouras. Eu quero pedir Para que me conduzam diante de seu rei; E os sacerdotes quero atiçar com suborno, Pra que me levem diante da mais forte efígie E se retirem, e fechem as portas dos templos. E quero ainda, quando souber muitas coisas, Contemplar os animais para que algo vindo De seu modo de ser se insinue nas minhas Articulações; quero ter, nos olhos deles, Uma existência breve que me ampare e, lenta Me permita estar tranquilo e sem julgamento. Quero ordenar aos jardineiros que enumerem Pra mim as muitas flores, para que nos cacos Dos belos nomes próprios possa resgatar Um resquício dos mil perfumes. E eu quero Comprar frutas, frutas, em cujo âmago a terra Mais uma vez está, vibrando até os céus.

Pois isso compreendeste: as frutas repletas. $\mathrm{Tu}$ as deitaste sobre cascas na tua frente E ainda sopesaste seu peso com as cores $\mathrm{E}$ assim como as frutas, também viste as mulheres E viste as crianças de dentro pra fora

A moldarem-se nas formas de sua existência, E viste a ti mesma por fim como uma fruta, Te colheste pra fora de tuas roupas, te Puseste ao espelho e te deixaste adentrá-lo Até alcançar o olhar que ali restou, imenso, 
ROSENFIELD, K.; PEREIRA, L. - Um diálogo inspirador no Réquiem a uma Amiga

und sagte nicht: das bin ich; nein: dies ist. So ohne Neugier war zuletzt dein Schaun und so besitzlos, von so wahrer Armut, dass es dich selbst nicht mehr begehrte: heilig.

So will ich dich behalten, wie du dich hinstelltest in den Spiegel, tief hinein und fort von allem. Warum kommst du anders? Was widerrufst du dich? Was willst du mir einreden, dass in jenen Bernsteinkugeln um deinen Hals noch etwas Schwere war von jener Schwere, wie sie nie im Jenseits beruhigter Bilder ist; was zeigst du mir in deiner Haltung eine böse Ahnung; was heißt dich die Konturen deines Leibes auslegen wie die Linien einer Hand, dass ich sie nicht mehr sehn kann ohne Schicksal?

Komm her ins Kerzenlicht. Ich bin nicht bang, die Toten anzuschauen. Wenn sie kommen, so haben sie ein Recht, in unserm Blick sich aufzuhalten, wie die andern Dinge.

Komm her; wir wollen eine Weile still sein. Sieh diese Rose an auf meinem Schreibtisch; ist nicht das Licht um sie genau so zaghaft wie über dir: sie dürfte auch nicht hier sein. Im Garten draußen, unvermischt mit mir, hatte sie bleiben müssen oder hingehn, nun währt sie so: was ist ihr mein Bewusstsein?

Erschrick nicht, wenn ich jetzt begreife, ach, da steigt es in mir auf: ich kann nicht anders, ich muss begreifen, und wenn ich dran stürbe. Begreifen, dass du hier bist. Ich begreife. Ganz wie ein Blinder rings ein Ding begreift, fühl ich dein Los und weiß ihm keinen Namen. Lass uns zusammen klagen, dass dich einer aus deinem Spiegel nahm. Kannst du noch weinen? Du kannst nicht. Deiner Tränen Kraft und Andrang hast du verwandelt in dein reifes Anschaun und warst dabei, jeglichen Saft in dir so umzusetzen in ein starkes Dasein, das steigt und kreist, im Gleichgewicht und blindlings. Da riss ein Zufall dich, dein letzter Zufall riss dich zurück aus deinem fernsten Fortschritt in eine Welt zurück, wo Säfte wollen.

Riss dich nicht ganz; riss nur ein Stück zuerst, doch als um dieses Stück von Tag zu Tag die Wirklichkeit so zunahm, dass es schwer ward, da brauchtest du dich ganz: da gingst du hin und brachst in Brocken dich aus dem Gesetz mühsam heraus, weil du dich brauchtest. Da trugst du dich ab und grubst aus deines Herzens nachtwarmem Erdreich die noch grünen Samen, daraus dein Tod aufkeimen sollte: deiner, dein eigner Tod zu deinem eignen Leben. Und aßest sie, die Körner deines Todes, wie alle andern, aßest seine Körner, und hattest Nachgeschmack in dir von Süße, die du nicht meintest, hattest süße Lippen, du: die schon innen in den Sinnen süß war.
E não disse: isso sou eu; mas: isso é.

E ao final teu olhar estava tão sem zelos,

Tão despossuído, tão pleno de humildade,

Que já nem desejava a si mesmo: sagrado.

E é assim que quero te guardar, no teu pairar

Em pé dentro do espelho, bem no fundo e longe

De tudo. Mas por que vens desse outro modo?

Por que te revogas? Queres me convencer

Que naquelas bolas de âmbar ao redor

De teu pescoço há ainda um certo peso,

Um peso que jamais existe para além

Das tranquilas imagens? Por que tu me mostras

$\mathrm{Na}$ tua compostura um mau augúrio? O que

Então te faz ler os contornos do teu corpo

Como as linhas de uma mão, e de tal maneira

Que eu já não posso mais mirá-las sem destino.

Vem cá dentro da luz da vela. Eu não temo

Fitar os mortos. Quando eles chegam assim

Eles possuem um direito de descansar

Em nosso olhar, como também as outras coisas.

Vem cá. Queremos por um tempo estar tranquilos.

Olha essa rosa na minha mesa; Não é

Tão tênue seu halo quanto o lume à tua volta?

Ela tampouco deveria estar aqui.

No jardim lá fora, sem se mesclar comigo,

Deveria ter se quedado ou então partido

E ei-la assim: pra ela, o que é minha consciência?

Não te assustes, quando agora passo a entender, Pois isso brota em mim: não posso de outro modo, Eu preciso entender, mesmo que eu morra disso. Entender que tu estás aqui. Isso eu entendo. Como um cego que compreende usando o toque, Tateio a tua sina, sem ter pra ela um nome. Deixa-nos lamentar que foste arrebatada De dentro do espelho. Ainda podes chorar? Não, não podes. A força e o jorro de tuas lágrimas Tu transfiguraste em madura visão.

E já estavas a transformar toda e qualquer

Seiva numa forte existência que se alça

E circula, cegamente, em bom equilíbrio.

E o acaso te extirpou, teu derradeiro acaso

Te extirpou para fora do teu longínquo ascenso,

Tragando-te no mundo onde as seivas querem.

Não te extraíste toda, só um ramo primeiro,

Mas, dia após dia, ao redor desse ramo

Tanto cresceu o real que se tornou difícil,

E precisaste inteira de ti, foste lá e,

Te quebraste, árdua, em detritos, transpondo

A lei. Precisavas de ti, te desmontaste,

E cavaste do chão do teu coração, tépido

Pela noite, as sementes ainda verdes

De onde tua morte brotaria: a tua morte, A tua própria morte para a tua própria vida.

E tu, tu os comeste, os grãos de tua morte,

Como todos os outros, comeste seus grãos,

E em ti sentiste a sobra de sabor do doce,

Inesperada, sentiste em teus doces lábios,

Tu: já tão doce por dentro em teus sentimentos. 
ROSENFIELD, K.; PEREIRA, L. - Um diálogo inspirador no Réquiem a uma Amiga

O lass uns klagen. Weißt du, wie dein Blut aus einem Kreisen ohnegleichen zögernd und ungern wiederkam, da du es abriefst? Wie es verwirrt des Leibes kleinen Kreislauf noch einmal aufnahm; wie es voller Misstraun und Staunen eintrat in den Mutterkuchen und von dem weiten Rückweg plötzlich müd war. Du triebst es an, du stießest es nach vorn, du zerrtest es zur Feuerstelle, wie man eine Herde Tiere zerrt zum Opfer; und wolltest noch, es sollte dabei froh sein. Und du erzwangst es schließlich: es war froh und lief herbei und gab sich hin. Dir schien, weil du gewohnt warst an die andern Maße, es wäre nur für eine Weile; aber nun warst du in der Zeit, und Zeit ist lang. Und Zeit geht hin, und Zeit nimmt zu, und Zeit ist wie ein Rückfall einer langen Krankheit.

Wie war dein Leben kurz, wenn du's vergleichst mit jenen Stunden, da du saßest und die vielen Kräfte deiner vielen Zukunft schweigend herabbogst zu dem neuen Kindkeim, der wieder Schicksal war. O wehe Arbeit. O Arbeit über alle Kraft. Du tatest sie Tag für Tag, du schlepptest dich zu ihr und zogst den schönen Einschlag aus dem Webstuhl und brauchtest alle deine Fäden anders. Und endlich hattest du noch Mut zum Fest.

Denn da's getan war, wolltest du belohnt sein, wie Kinder, wenn sie bittersüßen Tee getrunken haben, der vielleicht gesund macht. So lohntest du dich: denn von jedem andern warst du zu weit, auch jetzt noch; keiner hätte ausdenken können, welcher Lohn dir wohltut. Du wusstest es. Du saßest auf im Kindbett, und vor dir stand ein Spiegel, der dir alles ganz wiedergab. Nun war das alles $D u$ und ganz davor, und drinnen war nur Täuschung, die schöne Täuschung jeder Frau, die gern Schmuck umnimmt und das Haar kämmt und verändert.

So starbst du, wie die Frauen früher starben, altmodisch starbst du in dem warmen Hause den Tod der Wöchnerinnen, welche wieder sich schließen wollen und es nicht mehr können, weil jenes Dunkel, das sie mitgebaren, noch einmal wiederkommt und drängt und eintritt.

Ob man nicht dennoch hätte Klagefrauen auftreiben müssen? Weiber, welche weinen für Geld, und die man so bezahlen kann, dass sie die Nacht durch heulen, wenn es still wird. Gebräuche her! wir haben nicht genug Gebräuche. Alles geht und wird verredet. So musst du kommen, tot, und hier mit mir Klagen nachholen. Hörst du, dass ich klage? Ich möchte meine Stimme wie ein Tuch hinwerfen über deines Todes Scherben und zerrn an ihr, bis sie in Fetzen geht, und alles, was ich sage, müsste so
Oh, deixe-nos chorar. Sabes como teu sangue, Relutando, hesitando, deu meia-volta em sua Circulação sem par quando tu o convocaste, Como, absorveu, confuso, ainda uma vez, O humilde circuito do corpo? Como, pleno De assombro e suspeição ingressou na placenta $\mathrm{E}$ do longo retorno súbito se cansou.

$\mathrm{Tu}$ o propeliste, o empurraste para frente, E tu o arrojaste rumo ao fogo-lar, como Se arrasta ao sacrifício uma grei de animais; $E$ inda quiseste que ele fosse feliz nisso E enfim tu o forçaste: ele estava feliz, Correu até aqui e se entregou. Pareceu-te, Porque estavas habituada a outras medidas, Que seria apenas por um tempo; Porém, Estavas então no tempo, e o tempo é longo

E tempo passa, e tempo se dilata, e tempo

É qual um recair numa longa doença.

Como foi curta a tua vida, quando a comparas Com aquelas horas, quando te sentavas e às forças Várias te curvavas dos teus vários futuros,

Silenciosa, ante o tenro grão de uma criança Que novamente era destino. Ah, o ofício, Oh, Arte para além de nossas forças. Tu o fizeste Dia após dia, tu te arrastaste até ele,

Da liça do tear puxaste a bela trama E aplicaste todos os teus fios, tão variegados. E ainda ao fim tinhas ânimo para a festa.

Pois quando estava feito, tu quiseste ser Premiada, como as crianças quando bebem O agridoce chá que as torna talvez saudáveis. Assim te premiaste: pois estavas muito Longe de todos, e mesmo agora; ninguém Pôde idear qual prêmio te faria bem.

Tu sabias. Sentaste em teu leito de parto

E na tua frente havia um espelho que tudo

A ti refletia. O tudo era agora $T u$

Inteira ali na frente, e dentro só o engano, O belo engano de toda a mulher, que alegre Se cinge de joias, se penteia e se altera.

Assim morreste, como outrora as mulheres Morriam, morreste ao velho modo na casa Quente, a morte das parturientes que de novo Desejam se fechar e não o podem mais, Pois a sombra que elas também trouxeram à luz Retorna ainda mais uma vez e empurra e adentra.

Mas o certo não seria aqui ir em busca De carpideiras? Dessas mulheres que choram Por dinheiro e que podem ser remuneradas Pra noite adentro urrar, quando chega o silêncio? Retornem os costumes! Nos estão faltando Os costumes. Tudo vai, tudo é desfalado Pois tens que retornar, morta, e resgatar Os lamentos comigo. Ouves meu lamento? Eu queria lançar minha voz, como um pano, Por sobre os cacos e estilhaços de tua morte, Rompendo meu timbre até que fique em farrapos; E tudo o que eu disser deveria adentrar 
ROSENFIELD, K.; PEREIRA, L. - Um diálogo inspirador no Réquiem a uma Amiga

zerlumpt in dieser Stimme gehn und frieren; blieb es beim Klagen. Doch jetzt klag ich an: den Einen nicht, der dich aus dir zurückzog, (ich find ihn nicht heraus, er ist wie alle) doch alle klag ich in ihm an: den Mann.

Wenn irgendwo ein Kindgewesensein tief in mir aufsteigt, das ich noch nicht kenne, vielleicht das reinste Kindsein meiner Kindheit: ich wills nicht wissen. Einen Engel will ich daraus bilden ohne hinzusehn und will ihn werfen in die erste Reihe schreiender Engel, welche Gott erinnern.

Denn dieses Leiden dauert schon zu lang, und keiner kanns; es ist zu schwer für uns, das wirre Leiden von der falschen Liebe, die, bauend auf Verjährung wie Gewohnheit, ein Recht sich nennt und wuchert aus dem Unrecht. Wo ist ein Mann, der Recht hat auf Besitz? Wer kann besitzen, was sich selbst nicht hält, was sich von Zeit zu Zeit nur selig auffängt und wieder hinwirft wie ein Kind den Ball.

Sowenig wie der Feldherr eine Nike festhalten kann am Vorderbug des Schiffes, wenn das geheime Leichtsein ihrer Gottheit sie plötzlich weghebt in den hellen Meerwind: so wenig kann einer von uns die Frau anrufen, die uns nicht mehr sieht und die auf einem schmalen Streifen ihres Daseins wie durch ein Wunder fortgeht, ohne Unfall: er hätte denn Beruf und Lust zur Schuld.

Denn das ist Schuld, wenn irgendeines Schuld ist: die Freiheit eines Lieben nicht vermehren um alle Freiheit, die man in sich aufbringt. Wir haben, wo wir lieben, ja nur dies: einander lassen; denn dass wir uns halten, das fallt uns leicht und ist nicht erst zu lernen.

Bist du noch da? In welcher Ecke bist du? Du hast so viel gewusst von alledem und hast so viel gekonnt, da du so hingingst für alles offen, wie ein Tag, der anbricht. Die Frauen leiden: lieben heißt allein sein, und Künstler ahnen manchmal in der Arbeit, dass sie verwandeln müssen, wo sie lieben. Beides begannst du; beides ist in Dem, was jetzt ein Ruhm entstellt, der es dir fortnimmt.

Ach du warst weit von jedem Ruhm. Du warst unscheinbar; hattest leise deine Schönheit hineingenommen, wie man eine Fahne einzieht am grauen Morgen eines Werktags, und wolltest nichts, als eine lange Arbeit, die nicht getan ist: dennoch nicht getan.

Wenn du noch da bist, wenn in diesem Dunkel noch eine Stelle ist, an der dein Geist empfindlich mitschwingt auf den flachen Schallwelln, die eine Stimme, einsam in der Nacht, aufregt in eines hohen Zimmers Strömung:
A voz como um rasgão e depois congelar, Fosse isso só lamento. Mas agora eu acuso: Não quem te retraiu de dentro de ti mesma, (Não o aponto sozinho, ele é como todos)

Porém nele eu acuso a todos: o homem.

Se em algum lugar aquilo que foi ser criança,

Que ainda desconheço, se ergue no fundo em mim, Talvez o mais puro ser criança da infância: Isso não quero saber. Quero fazer disso Um anjo sem fixar os olhos. E quero também Lançá-lo na primeira fileira de anjos Que esbravejam e berram relembrando Deus.

Pois esse tormento já foi longe demais, Ninguém suporta; é duro demais para nós, O túrbido tormento que vem do falso amor, Que, forjado da prescrição como costume, Se arroga da justiça, mas grassa do injusto. Que homem há que tem direito à possessão? Como é possível ter o que não se sustenta,

O que só de tempo em tempo, na aventurança, Se resgata a si mesmo, para se lançar Novamente como um menino lança a bola. Possível tanto quanto pode o marechal Vislumbrar Nice na proa do navio, quando A oculta leveza da divindade súbito A soergue no esplendor do vento marinho: Por isso, entre nós, poucos podem invocar Essa mulher que já não mais nos vê e que Numa estreitada faixa de sua existência, Como por milagre, parte, sem acidente:

Salvo se ele achasse na culpa gozo e ofício. .

Pois isto é culpa, se é que alguma culpa exista: Não aumentar a liberdade do ente amado Com toda a liberdade que se traz em si. Nós temos, quando amamos, sim, somente isto: Deixar o outro ir, pois é fácil apoiar Um ao outro, e não requer aprendizado.

Estás ainda aí? Em que canto estás? -

E tu sabias tanto sobre tudo isso,

Podias fazer tanto, no tempo em que estavas

Aberta para tudo, como um dia raiando.

As mulheres sofrem: amar é estar sozinho,

E o artista em seu ofício às vezes intui

Que ele deve transmutar, sempre que ele ama.

São estas duas coisas que tu começaste,

Ambas se encontram naquilo que agora está

Enfeado pela fama que rouba de ti.

$\mathrm{Ah}$, estavas longe de qualquer fama. Tu não

Sobressaías; tinhas quieta recolhido

Tua beleza, como se enrola uma bandeira

Numa escura manhã de um dia de trabalho,

E nada quiseste salvo uma vasta obra

Que não está feita: mesmo assim não foi feita.

Se ainda estás aí, se ainda há um lugar

No breu da escuridão onde retine e vibra,

Sensível, teu espírito, em ondas de som

Que uma voz, isolada na noite, retine

Em meio à correnteza de um quarto elevado: 
ROSENFIELD, K.; PEREIRA, L. - Um diálogo inspirador no Réquiem a uma Amiga

So hör mich: Hilf mir. Sieh, wir gleiten so, nicht wissend wann, zurück aus unserm Fortschritt in irgendwas, was wir nicht meinen; drin wir uns verfangen wie in einem Traum und drin wir sterben, ohne zu erwachen. Keiner ist weiter. Jedem, der sein Blut hinaufhob in ein Werk, das lange wird, kann es geschehen, dass ers nicht mehr hochhält und dass es geht nach seiner Schwere, wertlos. Denn irgendwo ist eine alte Feindschaft zwischen dem Leben und der großen Arbeit. Dass ich sie einseh und sie sage: hilf mir.

Komm nicht zurück. Wenn du's erträgst, so sei tot bei den Toten. Tote sind beschäftigt. Doch hilf mir so, dass es dich nicht zerstreut, wie mir das Fernste manchmal hilft: in mir. (RILKE 1996: I pp. 414-421)
Então me ouve, ajuda. Vê, nós recuamos Sem saber quando, do alto de nossos avanços Para coisas que não intentamos, nas quais Nós nos enredamos como se fosse um sonho No imo do qual morremos, sem nem despertar. Ninguém está à frente. Àquele que alce Seu sangue numa obra que há de ser longa Pode ocorrer de não poder sustê-la alto E a obra assim evolve em vão na sua inércia. Pois em algum lugar existe uma ancestral Hostilidade entre a vida e a grande obra. Que eu a veja e ela me diga: me ajuda. Não volta mais. Se tu podes suportar, sede Uma morta entre os mortos: tão atarefados. Mas me ajuda e que isso não te distraia, como Me ajuda amiúde o mais além: dentro de mim. 
ROSENFIELD, K.; PEREIRA, L. - Um diálogo inspirador no Réquiem a uma Amiga

\section{PAULA MODERSOHN-BECKER: RESUMO BIOGRÁFICO}

Paula Modersohn-Becker nasce a 8 fevereiro de 1876, vindo a falecer após o parto de sua única filha, no dia 20 de novembro de 1907. Tendo pais cultos, Paula recebe uma educação cuidadosa. Suas primeiras aulas de pintura acontecem durante estada com uma tia em Londres, em 1888, na escola Saint John's Wood Art School.

Entre 1893-1895, recebe educação em desenho e pintura em Bremen; em 1895, faz os primeiros contatos com artistas do círculo de Worpswede: Fritz Mackensen, Otto Modersohn, Fritz Overbeck e Heinrich Vogeler. Em 1897, passa o verão em Worpswede, depois viaja a Dresden, Berlin e Wien, no outono. Em dezembro de 1899, participa de uma exposição coletiva na Kunsthalle Bremen. Sua obra, que já tem traços primitivistas, é duramente criticada e removida da exposição no dia seguinte ao vernissage. Nos dias seguintes, ela viaja com sua amiga-escultora Clara Westhoff para passar os meses de janeiro a julho de 1900 em Paris. Após o retorno a Worpswede, ela casa, em 1902, com Otto Modersohn (que perdera a esposa no verão de 1900); com o marido, a enteada e uma empregada, ela consegue assegurar um ateliê e horários de trabalho artístico ao abrigo das exigências domésticas que uma vida burguesa teria exigido da esposa. No ano seguinte, em fevereiro e março de 1903 e durante os primeiros quatro meses (fevereiro a abril) de 1905, o casal passa de novo um tempo em Paris.

No final de 1905, Rilke encoraja a artista a perseguir uma carreira como pintora e, em seguida, Paula acelera formidavelmente seu trabalho artístico. Em fevereiro de 1906, ela viaja a Paris, onde um outro artista, Bernard Hoetger, descobre seu talento e a encoraja. Assim ela decide abandonar Otto Modersohn, informando-lhe por carta, o que o deixa chocado diante da decisão totalmente inesperada. No entanto, considerações sobre a viabilidade de assumir uma vida solitária sem o marido e a enteada (e de se sustentar como pintora independente) a levam de volta a Worpswede.

Em 20 de novembro 1907, alguns dias após dar à luz Mathilde, Paula ModersohnBecker morre de uma embolia. Suas últimas palavras teriam sido: “Que pena!".

\section{Referências bibliográficas}

BARRETO, Matheus Guménin. "Dança de força": elementos estruturais em três traduções de Rainer Maria Rilke. Cadernos de Tradução, v. 40, n. 3, 109-131, set-dez 2020. Online: https://periodicos.ufsc.br/index.php/traducao/article/view/2175-7968.2020v40n3p109. $(20 / 05 / 2021)$.

BAZAN, Mariana Marchi. Poesia-coisa: a poesia de Rilke em diálogo com a escultura e a pintura. Dissertação (Mestrado em Literatura) - Centro de Comunicação e Expressão, Universidade Federal de Santa Catarina, Florianópolis, 2018.

Benjamin, Walter. Gesammelte Schriften. Frankfurt am Main: Suhrkamp, 1980. 12 v.

BENJAmin, Walter. Rainer Maria Rilke und Franz Blei. In: Benjamin, Walter. Gesammelte Schriften: Band IV: Kleine Prosa. Baudelaire-Übertragungen. Frankfurt am Main: Suhrkamp, 1980, 453. v. IV, (1,2).

Pandaemonium, São Paulo, v. 24, n. 44, set.-dez. 2021, p. 271-295 
ROSENFIELD, K.; PEREIRA, L. - Um diálogo inspirador no Réquiem a uma Amiga

Chagas, Laura Monteiro. O projeto estético de Rilke nas Anotações de Malte Laurids Brigge. Dissertação (Mestrado em Língua e Literatura Alemã) - Faculdade de Filosofia, Letras e Ciências Humanas, Universidade de São Paulo, São Paulo, 2019.

Costa, Alexandre Rodrigues da. A transfiguração do olhar: um estudo das relações entre artes visuais e literatura em Rainer Maria Rilke e Clarice Lispector. Belo Horizonte: Editora UEMG, 2019.

ECKEL, Winfried. [Rilkes] Dichtungen und Schriften. In: ENGEL, Manfred (org.). Rilke Handbuch: Leben - Werk - Wirkung. Stuttgart: Metzler, 2013, pp. 130 ss.

ENGEL, Manfred (org.). Rilke-Handbuch: Leben - Werk - Wirkung. Stuttgart: J.B. Metzler, 2013.

FREUD, Sigmund. Gesammelte Werke, 18 vols., Fischer Verlag, Frankfurt, 1981. Vol. X, 428-46: Trauer und Melancholie (1917); vol. XII, 321-4: Einleitung zur Psychoanalyse der Kriegsneurosen (1918/19).

FRICKE, H.; GRUBMÜLLER, K.; MÜLLER, J.D. Reallexikon der deutschen Literaturwissenschaft. Berlin; New York: Walter de Gruyter, 1997 - 2003, 367f. Band I.

FÜLLHORN, Ulrich. Comentário da edição RILKE, Rainer Maria. Werke. Kommentierte Ausgabe in vier Bänden. Frankfurt am Main: Insel Verlag, 1996.

HellingRath, Norbert von. Pindarübertragungen von Hölderlin: Prolegomena zu einer Erstausgabe. Jena: Diederichs, 1911, 1-25. Online: http://www.lyriktheorie.uniwuppertal.de/texte/1911_hellingrath.html. (20/05/2021)

HOFMANN, Paul. Hellingrath's dichterische Rezeption Hölderlins. In: KURZ, G.; LAWITSCHKA, V.; WertheIMER, J. (eds.). Hölderlin und die Moderne, Eine Bestandaufnahme. Tübingen: Attempto, 1995, 74-103.

Hofmannsthal, Hugo von. Uma Carta [de Lord Chandos]. In: NuÑEz, Carlinda Fragale Pate; Monteiro, Maria Conceição (orgs.). A Tradução em Perspectiva. Trad. Carlinda Fragale Pate Nuñez. Rio de Janeiro: Editora Caetés, 2009, 89-97.

MÜLLER, Wolfgang. "Neue Gedichte / Der Neuen Gedichte anderer Teil". In: ENGEL, Manfred (org.). Rilke-Handbuch: Leben - Werk - Wirkung. Stuttgart: J.B. Metzler, 2013, 296317.

MUSIL, Robert. Rede zur Rilke-Feier in Berlin am 16. Januar 1927. In: MUSIL, Robert. Kleine Prosa und Schriften. Reinbek bei Hamburg: Rowohlt, 1978, 1237-1242.

PEREZ, Juliana. Vida que se recolhe ao Invisível. IFE - Instituto de Formação e Educação, 2017. Online: http://ife.org.br/vida-recolhe-invisivel-rilke-juliana-perez/ (18/12/2020).

PoR, Peter. Verzerrung und Versagen des Wortes an dem Bruch in der Welt. Eine Lektüre von R.s zweiteiligem Requiem-Zyklus. Recherches Germaniques, v. 28, 55-96, 1998.

PRADO, Paulo. Retrato do Brasil: Ensaio sobre a tristeza brasileira. Rio de Janeiro: Livraria José Olympio, 1962.

Rilke, Rainer Maria. Cartas sobre Cézanne. Trad. Pedro Süsskind. São Paulo: 7 Letras, 2001.

RILKE, Rainer Maria. Werke. Kommentierte Ausgabe in vier Bänden. Frankfurt am Main: Insel Verlag, 1996.

RILKE, Rainer Maria. Worpswede (1902), In: Werke. Kommentierte Ausgabe in vier Bänden. Frankfurt am Main: Insel Verlag, 1996, vol. IV, p. 305-400.

Rios, Rita. Poemas e Pedras: A relação entre a escultura e a poesia partindo de Rodin e Rilke. São Paulo: EDUSP, 2011.

SCHNITZLER, Arthur. Das weite Land. Frankfurt: S. Fischer, 1961.

SERPA, Danilo Chiovatto, Versos da lembrança e continuidade da poesia. Reflexões sobre o poeta e a lírica na representação do mito de Orfeu em Rilke, Trakl, Bachmann. Tese (Doutorado em Língua e Literatura Alemã) - Faculdade de Filosofia, Letras e Ciências Humanas, Universidade de São Paulo, São Paulo, 2019. Online: https://www.teses.usp.br/teses/disponiveis/8/8144/tde-05122019164932/publico/2019_DaniloChiovattoSerpa_VOrig.pdf (11/02/2021).

Pandaemonium, São Paulo, v. 24, n. 44, set.-dez. 2021, p. 271-295 
ROSENFIELD, K.; PEREIRA, L. - Um diálogo inspirador no Réquiem a uma Amiga

STERn, Fritz. The Politics of Cutural Despair: a study in the Rise of the Germanic Ideology. Berkeley: University of California Press, 1974.

StORCK, Joachim W. [Rilkes] Leben und Persönlichkeit. In: Engel, Manfred (ed.). RilkeHandbuch: Leben - Werk - Wirkung. Stuttgart: Metzler, 2013, 1-26.

Recebido em 23 de dezembro de 2020 Aceito em 25 de fevereiro de 2021 